\title{
Article
}

http://dx.doi.org/10.11646/phytotaxa.170.4.4

\section{Gagea antakiensis, a new species from Southern Anatolia, Turkey and the new finding of Gagea lojaconoi (Liliaceae)}

\author{
SAMIM KAYIKÇI ${ }^{1}$, ATILA OCAK $^{2}$, MEHTAP TEKȘEN $^{3 *} \&$ SEHER KARAMAN ERKUL ${ }^{3}$ \\ ${ }^{I}$ Department of Biology, Faculty of Science and Arts, Mustafa Kemal University, 31000 Antakya - Turkey \\ ${ }^{2}$ Department of Biology, Faculty of Science and Arts, Eskişehir Osmangazi University, 26480 Eskişehir - Turkey \\ ${ }^{3}$ Department of Biology, Faculty of Science and Arts, Aksaray University, 68100 Aksaray -Turkey; e-mail: mteksen2431@gmail.com \\ *Author for correspondence
}

\begin{abstract}
Gagea antakiensis (Liliaceae) is described and illustrated as a new species from Hatay province in South Anatolia, Turkey. The new species belongs to the section Didymobulbos, based on morphological features, and it is close to G. lojaconoi. The samples belonging to $G$. chrysantha species group in the Flora of Turkey were confirmed as G. lojaconoi. A taxonomic description, an illustration of the new species, geographical distribution, habitat and ecology, conservation status of the new species and its affinity to G. lojaconoi and G. chrysantha species group are given in this study. In addition, the anatomical features of $G$. antakiensis and G. lojaconoi are given.
\end{abstract}

Key words: taxonomy, Didymobulbos, Antakya

\section{Introduction}

Gagea Salisbury (1806: 555) (incl. Lloydia Salisb. ex Reichenbach (1830: 102) is one of the 15 genera currently included in the family Liliaceae (Tribe Tulipeae) and is represented by approximately 280 (Peruzzi 2012a) to 300 species worldwide (Tison et al. 2013). The members of the genus are largely distributed across the temperate and subtropical regions of Eurasia, Europe, and Western Asia, with a few species in North Africa and North America (Zarrei et al. 2007, 2010a, 2010b, Peruzzi 2012a). Mediterranean species represent about 25\% of the existing species from all Gagea sections (Peruzzi 2008a). In Turkey, this genus has 26 species and one subspecies, two of which are endemic (Rix 1984, Hamzaoğlu et al. 2008, Tison et al. 2013).

In the recent years, many researchers have contributed to taxonomy within the genus (Ali \& Levichev 2007, Levichev 1999, 2006, Levichev \& Ali 2006, Peruzzi 2003, 2008a, 2012b, Peruzzi et al. 2007, 2008a, 2008b, 2009a, 2009b, 2011, Peruzzi \& Bartolucci 2006, Peterson et al. 2004, 2008, 2009, 2010, 2011, Schnittler et al. 2013, Tison et al. 2013, Zarrei et al. 2007, 2009, 2010a, 2010b, 2010c, 2011). Currently, the genus Gagea includes 15 sections, mainly distinguished according to the morpho-anatomic and ontogenetic features of the basal and cauline leaves, peduncle, pedicels, tepals, and seeds (Peterson et al. 2008, Peruzzi 2012a).

Gagea has not been studied well worldwide because it is a taxonomically very problematic genus (Townsend \& Guest 1985, Levichev 1999, Peruzzi 2003, 2008a, Peterson et al. 2004, Zarrei et al. 2007, 2011). The range of variation in morphological characters is limited, making species recognition more difficult. Polyploidy, hybridization, and convergent evolution make species boundaries unclear (Levichev 1990, Gutierrez Esteban et al. 2009, Peruzzi et al. 2009a, 2011, Peruzzi 2008a, 2008b, 2012b, Peterson et al. 2009, 2011). Their short habit and inconspicuous appearance mean that they have often been ignored by collectors so that there is a shortage of herbarium specimens (Zarrei et al. 2011).

Gagea longifolia Lojacono (1908: 133) was published and was named contrary to the rules (nom. illeg.) by Lojacono, and was typified by Peruzzi \& Tison (2005), who also published a photo of the lectotype. Hence, a replaced synonym was proposed, namely Gagea lojaconoi (Peruzzi 2008: 145). These authors also stated that the G. chrysantha group needs further study (Peruzzi \& Tison 2005, Peruzzi et al. 2009b). Tison et al. (2013) exclude the presence in Turkey of $G$. chrysantha (endemic to Sicily: Peruzzi \& Tison 2005, 2007, Peruzzi et al. 2008a, 2009b, Tison et al. 2013), and state that Turkish populations might be referred to G. amblyopetala Boissier (1846: 107) or G. lojaconoi. 
G. antakiensis is distributed in South Anatolia, while G. lojaconoi is distributed in North West Turkey. Flowering time of G. antakiensis is late January and February, and possible fruting time is late February and early March. Nevertheless, flowering time of G. lojaconoi is March and early May, and fruting time is late May and June. $G$. lojaconoi has been until now confused with G. chrysantha in the Flora of Turkey (Rix 1984).

\section{Acknowledgements}

We would like to thank Assoc. Prof. Dr. Lütfü SAVAŞ, The Mayor of Antakya Municipality, for supporting this study within "The Book Project of Antakya Plants" and TUBITAK for its financial support (Project number KBAG109T950).

\section{References}

Ali, S.I. \& Levichev, I.G. (2007) Gagea. In: Ali, S.I. \& Qaiser, M. (eds.) Flora of Pakistan: Liliaceae. Missouri Botanical Press, USA, pp. $17-81$.

Feinbrun-Dothan, N. (1986) Flora Palaestina 4. Jerusalem Academic Press, Jerusalem, 33 pp.

Grossheim, A.A. (1935) Gagea Salisb. In: Komarov, V.L. (ed.) Flora USSR 4, Israel Program for Scientific Translation Ltd., pp. 61-112. Gutierrez Esteban, M., Lopez, J.L. \& Vazquez, F.M. (2009) World bibliographic revision of the chromosome number in the Gagea Salisb. (Liliaceae) species. Folia Botanica Extremadurensis 4: 45-57.

Hamzaoğlu, E., Budak, Ü. \& Aksoy, A. (2008) A New Species of Gagea Salisb. (Liliaceae) from Sivas (Central Anatolia, Turkey). Turkish Journal of Botany 32: 61-264.

Heywood, V.H. (1980) Lloydia Salisb. ex Rchb. In: Tutin, T.G., Heywood, V.H., Burges, N.A. \& Valentine, D.H. (eds.) Flora Europaea 5. Cambridge University Press, Cambridge, UK, pp. 26-28.

IUCN (2010) The IUCN red list of threatened species, version 2010.4. IUCN Red List Unit, Cambridge U.K. Available from: http://www. iucnredlist.org/ (accessed: 20 April 2013). http://dx.doi.org/10.5962/bhl.title.44776

Levichev, I.G. (1990) On age variation and hybridization of some representatives of Gagea (Liliaceae). Botanicheskii Zhurnal 75: 656667.

Levichev, I.G. (1999) The morphology of Gagea Salisb. (Liliaceae) I. Subterranean organs. Flora 194: 379-392.

Levichev, I.G. (2006) A review of the Gagea (Liliaceae) species in the flora of Caucasus. Botanicheskii Zhurnal 91: 917-951.

Levichev, I.G. \& Ali, S.I. (2006) Seven new species of the genus Gagea Salisb. (Liliaceae) from Western Himalayas and adjoining regions. Pakistan Journal of Botany 38: 55-62.

Peruzzi, L. (2003) Contribution to the cytotaxonomical knowledge of Gagea Salisb. (Liliaceae) sect. Foliatae A.Terracc. and synthesis of karyological data. Caryologia 56: 115-128. http://dx.doi.org/10.1080/00087114.2003.10589314

Peruzzi, L. (2008a) Contribution to the cytotaxonomical knowledge of the genus Gagea Salisb. (Liliaceae). III. New karyological data from the central Mediterranean area. Caryologia 61: 92-106. http://dx.doi.org/10.1080/00087114.2008.10589615

Peruzzi, L. (2008b) Hybridity as a main evolutionary force in Gagea Salisb. (Liliaceae). Plant Biosystems 142: $179-184$. http://dx.doi.org/10.1080/11263500701873042

Peruzzi, L. (2012a) Nomenclatural novelties at sectional level in Gagea (Liliaceae). Atti della Società Toscana di Scienze Naturali, Memorie, serie B 118 (2011): 23-24.

Peruzzi, L. (2012b) Chromosome diversity and evolution in the genus Gagea (Liliaceae). Bocconea 24: 147-158.

Peruzzi, L. \& Bartolucci, F. (2006) Gagea luberonensis J.-M.Tison (Liliaceae) new for the Italian flora. Webbia 61: 1-12.

http://dx.doi.org/10.1080/00837792.2006.10670789

Peruzzi, L., Bartolucci, F., Frignani, F. \& Minutillo, F. (2007) Gagea tisoniana, a new species of Gagea Salisb. sect. Gagea (Liliaceae) from central Italy. Botanical Journal of the Linnean Society 155: 337-347. http://dx.doi.org/10.1111/j.1095-8339.2007.00710.x

Peruzzi, L., Leitch, I.J. \& Caparelli, K.F. (2009a) Chromosome diversity and evolution in Liliaceae. Annals of Botany (London) 103: $459-475$.

http://dx.doi.org/10.1093/aob/mcn230 
Peruzzi, L., Peterson, A., Tison, J.M. \& Harpke, D. (2011) New light on phylogeny and taxonomy of the Eurasian Gagea villosa-G. fragifera group (Liliaceae). Nordic Journal of Botany 29: 722-733.

http://dx.doi.org/10.1111/j.1756-1051.2011.01187.x

Peruzzi, L., Peterson, A., Tison, J.M. \& Peterson, J. (2008a) Phylogenetic relationships of Gagea Salisb. (Liliaceae) in Italy, inferred from molecular and morphological data matrices. Plant Systematics and Evolution 276: 219-234. http://dx.doi.org/10.1007/s00606-008-0081-4

Peruzzi, L., Scuderi, L. \& Raimondo, F.M. (2009b) Distribution of the genus Gagea (Liliaceae) in Sicily. Flora Mediterranea $19: 25-47$.

Peruzzi, L., Tison, J.M., Peterson, A., \& Peterson, J. (2008b) On the phylogenetic position and taxonomic value of Gagea trinervia (Viv.) Greuter and Gagea sect. Anthericoides A.Terracc. (Liliaceae). Taxon 57: 1201-1214.

Peruzzi, L. \& Tison, J.M. (2005) Typification and taxonomic status of six taxa of Gagea Salisb. Liliaceae) described from Sicily and conserved at Palermo (PAL). Candollea 60: 503-512.

Peruzzi, L. \& Tison, J.M. (2007) Typification of six critical Mediterranean Gagea Salisb. (Liliaceae) species. Candollea 62: 173-188.

Peterson, A., Harpke, D., Peruzzi, L., Tison, J.-M., John H. \& Peterson J. (2010) Gagea bohemica (Liliaceae), a highly variable monotypic species within sect. Didymobulbos. Plant Biosystems 144: 308-322.

http://dx.doi.org/10.1080/11263500903374625

Peterson, A., John, H., Koch, E. \& Peterson, J. (2004) A molecular phylogeny of the genus Gagea (Liliaceae) in Germany inferred from non-coding chloroplast and nuclerar DNA sequences. Plant Systematics and Evolution 245: $145-162$. http://dx.doi.org/10.1007/s00606-003-0114-y

Peterson, A., Levichev, I.G. \& Peterson, J. (2008) Systematics of Gagea and Lloydia (Liliaceae) and infrageneric classification of Gagea based on molecular and morphological data. Molecular Phylogenetics and Evolution 46: 446-465.

http://dx.doi.org/10.1016/j.ympev.2007.11.016

Peterson, A., Harpke, D., Peruzzi, L., Levichev, I.G., Tison, J.M. \& Peterson, J. (2009) Hybridization drives speciation in Gagea (Liliaceae). Plant Systematics and Evolution 278: 133-148.

http://dx.doi.org/10.1007/s00606-008-0102-3

Peterson, A., Levichev, I.G., Peterson, J., Harpke, D. \& Schnittler, M. (2011) New insights into the phylogeny and taxonomy of Chinese species of Gagea (Liliaceae) - speciation through hybridization. Organism Diversity and Evolution 11: 387-407. http://dx.doi.org/10.1007/s13127-011-0059-x

Post, G.E. (1932) Flora of Syria, Palestine and Sinai 2. American Press, Beirut, 624 pp.

Reichenbach, H.G.L. (1830) Flora germanica excursoria ex affinitate regni vegetabilis naturali disposita, sive principia synopseos plantarum in Germania terrisque in Europa media adjacentibus sponte nascentium cultarumque frequentius 1. -Leipzig, 102 pp. http://dx.doi.org/10.5962/bhl.title.309

Rix, E.M. (1984) Gagea Salisb. In: Davis, P.H. (ed.) Flora of Turkey and the East Aegean Islands 8. Edinburgh University Press, Edinburgh, pp. 312-327.

Salisbury, R.A. (1806) On the characters of a distinct genus hitherto confounded with Ornithogalum, and called Gagea; with some remarks on the importance of the inflorescence in distinguishing genera. Annals of Botany (London) 2: 553-557.

Schnittler, M., Peterson, A., Peterson, J., Beisenova, S., Bersimbaevd, R.I. \& Pfeiffer, T. (2013) Minor differences with big consequences: Reproductive patterns inthe genus Gagea (Liliaceae). Flora 208: 591-598.

http://dx.doi.org/10.1016/j.flora.2013.09.002

Stroh, G. (1937) Die Gattung Gagea Salisb. Beihefte zum Botanischen Centralblatt 57: 485-520.

Thiers, B. (2014) Index Herbariorum: A global directory of public herbaria and associated staff. New York Botanical Garden's Virtual Herbarium. Available from http://sweetgum.nybg.org/ih/ (accessed: 16 april 2014).

Tison, J.M., Peterson, A., Harpke, D. \& Peruzzi, L. (2013) Reticulate evolution of the critical Mediterranean Gagea sect. Didymobulbos (Liliaceae) and its taxonomic implications. Plant Systematics and Evolution 299: 413-438.

http://dx.doi.org/10.1007/s00606-012-0731-4

Townsend, C.C. \& Guest, E. (1985) Gagea Salisb. In: Townsend, C.C. \& Guest, E. (eds.) Flora of Iraq 8. Ministry of Agriculture \& Agrarian Reform Republic of Iraq, Baghdad, pp. 65-75.

Zarrei, M., Zarre, S., Wilkin, P. \& Rix, E.M. (2007) Systematic revision of the genus Gagea Salisb. (Liliaceae) in Iran. Botanical Journal of the Linnean Society 154: 559-588. http://dx.doi.org/10.1111/j.1095-8339.2007.00678.x

Zarrei, M., Wilkin, P., Fay, M.F., Ingrouille, M.J., Zarre, S. \& Chase, M.W. (2009) Molecular systematics of Gagea and Lloydia (Liliaceae; Liliales): implications of analyses of nuclear ribosomal and plastid DNA sequences for infrageneric classification. Annals of Botany (London) 104: 125-142.

http://dx.doi.org/10.1093/aob/mcp103

Zarrei, M., Wilkin, P., Ingrouille, M.J., Zarre, S. \& Chase, M.W. (2010a) The systematic importance of anatomical data in Gagea (Liliaceae) 
from the Flora Iranica area. Botanical Journal of the Linnean Society 164: 155-177.

http://dx.doi.org/10.1111/j.1095-8339.2010.01081.x

Zarrei, M., Wilkin, P., Ingrouille, M.J. \& Chase, M.W. (2010b) Gagea calcicola (Liliaceae), a new species from southwestern Iran. Kew Bulletin 65: 89-96.

http://dx.doi.org/10.1007/s12225-010-9185-4

Zarrei, M., Wilkin, P., Ingrouille, M.J. \& Chase, M.W. (2010c) Gagea robusta (Liliaceae), a new species from Flora Iranica area. Kew Bulletin 65: 327-336.

http://dx.doi.org/10.1007/s12225-010-9196-1

Zarrei, M., Wilkin, P., Noltie, H.J., Ingrouille, M.J. \& Chase, M.W. (2011) A revised infrageneric classification for Gagea Salisb. (Tulipeae; Liliaceae): insights from DNA sequence and morphological data. Phytotaxa 15: 44-56.

APPENDIX 1. Specimens investigated of Gagea chrysantha species group.

G. lojaconoi:-ITALY: Sicily, Ficuzza nella via che da Godrano conduce al Gurgo Lungo-vicino a Quercus fontanesii negli aperti sopra la strada, 22 March 1829, Tineo (Lectotypedesignated by Peruzzi \& Tison 2005, PAL photo!); TURKEY: Kırklareli, above Kastros, 20 March 1974, A. Baytop 27248 (E!); Taşă̆ıl-Babaeski, steppe, 95 m, 6 April 2011, M. Tekşen 2766 \& S. Karaman (GAZI!); Taşağıl-Babaeski, steppe, 106 m, 7 April 2011, M. Tekşen 2768 \& S. Karaman (GAZI!); Edirne: Babaeski to Havsa, nr. Sinit, 25 March 1974, A. Baytop 27260 (E!); İstanbul: Nezahat Gökyiğit Botanic Garden, scrubs, wet places, 67 m, 5 April 2011, M. Tekşen 2765 \& S. Karaman (GAZI); ibidem, 7 June 2011, M. Tekşen 2865 \& S. Karaman (GAZI!); Çamlıca, 4 April 1974, A. Baytop 27334 (E!); Heybeli Ada (Halki), ca. 30 m, 24 March 1957, Davis 26235 \& Hedge (E!, ANK!); Kayışdağ, 5 March 1952, A. Berk 2597 (HUB!); Eyüp, 2 February 1936, Gassner 186 (ANK!); Bursa: Uludağ, Kirazlı, 14 May 1955, M. Heilbornn ISTF 14154 (ISTF!); Uludağ, Kirazlıyayla, 17 May 1944, M. Heilbornn ISTF 2908 (ISTF!); Uludağ, Elmaçukuru, 13 May 1944, M. Başarman ISTF 2849 (ISTF!); Uludağ, 16 May 1944, M. Başarman ISTF 2867 (ISTF!); Halkalı, meadows and hills, 3 April 1965, B. Tutel ISTF 19136 (ISTF!); Bakırköy, Ispartakule train station-Ömerli Boğaz, cultivated fields, 15 March 1978, İ. Delice, R. Öztürk ISTF 31235 (ISTF!); Adalar, Kinalıada, machhie, 6 April 1967, H. Demiriz, B. Tutel, ISTF 21946 (ISTF!); Belgrat forest, ca. 105 m, 15 March 1935, Balls 2071 (ANK!); Balıkesir: Simav to Sindırg1, 42 km to Sindırg1, 31 March 1973, T. Baytop 23994 (E!).

G. chrysantha:-Italy, Sicily, Ficuzza, 1829, Jan (lectotype designated by Peruzzi \& Tison 2007, G!).

G. amblyopetala:-Greece in montibus Atticae Parnes, s.d., Heldreich (lectotype designated by Stroh 1937, B photo!) 